\title{
VALIDASI PENGUKURAN OSMOLALITAS DENGAN MENGGUNAKAN LARUTAN STANDAR PADA ALAT AUTOMATIC OSMOMETER
}

\author{
Amal Rezka Putra, Maskur, Yayan Tahyan \\ Pusat Teknologi Radioisotop dan Radiofarmaka-BATAN, Tangerang Selatan, Indonesia \\ amalrezka@batan.go.id
}

\begin{abstract}
ABSTRAK
VALIDASI PENGUKURAN OSMOLALITAS DENGAN MENGGUNAKAN LARUTAN STANDAR PADA ALAT AUTOMATIC OSMOMETER. Salah satu syarat sediaan farmasi, khususnya sediaan injeksi intravena, adalah penentuan nilai osmolalitas. Alat yang digunakan untuk menentukan nilai osmolalitas adalah automatic osmometer. Sebelum digunakan secara rutin untuk menentukan osmolalitas sediaan radiofarmaka, diperlukan validasi automatic osmometer untuk memastikan bahwa hasil pengukuran alat tersebut valid. Validasi pengukuran osmometer dilakukan dengan tiga parameter, yaitu akurasi, presisi, dan linearitas. Sebagai objek pengukuran diambil larutan standar $100 \mathrm{mOsm} / \mathrm{kg}, 290 \mathrm{mOsm} / \mathrm{kg}$, dan 500 $\mathrm{mOsm} / \mathrm{kg}$. Masing-masing larutan diukur sebanyak $20 \mathrm{kali}$, lalu dibuat tabel akurasi, grafik presisi, dan grafik linearitas. Persentase akurasi pada standar $100 \mathrm{mOsm} / \mathrm{kg}=100,05 \%, 290 \mathrm{mOsm} / \mathrm{kg}=100,05 \%$, dan $500 \mathrm{mOsm} / \mathrm{kg}=100,42 \%$. Validasi presisi pengukuran standar $100 \mathrm{mOsm} / \mathrm{kg}$ menunjukkan nilai $\pm 1 \mathrm{SD}=$ $50 \%, \pm 2 \mathrm{SD}=50 \%$, standar $290 \mathrm{mOsm} / \mathrm{kg} \pm 1 \mathrm{SD}=80 \%, \pm 2 \mathrm{SD}=15 \%$, dan $\pm 3 \mathrm{SD}=5 \%$, dan standar 500 $\mathrm{mOsm} / \mathrm{kg} \pm 1 \mathrm{SD}=75 \%, \pm 2 \mathrm{SD}=25 \%$. Nilai linearitas pada rerata hasil pengukuran adalah $\mathrm{a}=1,00520, \mathrm{~b}$ $=0,77533$, dan $r^{2}=0,99999$. Dari hasil validasi pengukuran nilai osmolalitas larutan standar dengan alat automatic osmometer dinyatakan bahwa alat tersebut valid untuk digunakan dalam pengukuran osmolalitas sediaan radiofarmaka.
\end{abstract}

Kata kunci: validasi, osmometer, osmolalitas, larutan standar

\begin{abstract}
VALIDATION OF OSMOLALITY MEASUREMENT USING STANDARD SOLUTION ON AUTOMATIC OSMOMETER. One of the requirements of intravenous injection preparation is determination of osmolality. The instrument used to determine osmolality value is automatic osmometer. Before being used routinely to determine osmolality of radiopharmaceutical preparation, automatic osmometer validation is needed to ascertain whether the result of the measurement is still valid or not. Measurement validation of osmometer is performed by three parameters: accuracy, precision, and linearity. Object of measurement was standard solution of $100 \mathrm{mOsm} / \mathrm{kg}, 290 \mathrm{mOsm} / \mathrm{kg}$ and $500 \mathrm{mOsm} / \mathrm{kg}$, each measured 20 times. Subsequently, table of accuracy, precision graphs and linearity graph were investigated. The percentage of accuracy on a standard of $100 \mathrm{mOsm} / \mathrm{kg}, 290 \mathrm{mOsm} / \mathrm{kg}$, and $500 \mathrm{mOsm} / \mathrm{kg}$ was $100.05 \% ; 100.05 \% ; 100.42 \%$ respectively. Validation of measurement precision standard of $100 \mathrm{mOsm} / \mathrm{kg}$ showed a value of $\pm 1 \mathrm{SD}=50 \%, \pm 2 \mathrm{SD}=$ $50 \%$, the standard of $290 \mathrm{mOsm} / \mathrm{kg} \pm 1 \mathrm{SD}=80 \%, \pm 2 \mathrm{SD}=15 \%$, and $\pm 3 \mathrm{SD}=5 \%$, and the standard of $500 \mathrm{mOsm} / \mathrm{kg} \pm 1 \mathrm{SD}=75 \%, \pm 2 \mathrm{SD}=25 \%$. Linearity value of the average measurement result was $a=$ $1.00520, b=0.77533$ and $r^{2}=0.99999$. Results of the validation of osmolality measurement using standard solution on automatic osmometer showed that the instrument was valid for the purpose of osmolality measurement of radiopharmaceutical preparations.
\end{abstract}

Keywords: validation, osmometer, osmolality, standard solution 


\section{PENDAHULUAN}

Pusat Teknologi Radioisotop dan Radiofarmaka (PTRR) BATAN merupakan lembaga yang bergerak di bidang penelitian pengembangan radioisotop dan radiofarmaka. Pada umumnya sediaan radiofarmasi yang diproduksi secara komersial ataupun konvensional harus melalui uji fisikokimia dan uji biologi. Uji fisikokimia sediaan radiofarmasi meliputi pengujian kejernihan, osmolalitas, $\mathrm{pH}$, kemurnian radionuklida, dan kemurnian radiokimia. Adapun uji biologi sediaan radiofarmasi meliputi uji sterilitas dan uji pirogenitas [1].

Salah satu parameter untuk menetapkan kelayakan suatu sediaan injeksi steril yang disuntikkan langsung melalui intravena adalah osmolalitas. Osmolalitas adalah ukuran jumlah partikel yang aktif secara osmotik dalam satu kilogram air. Pada serum orang dewasa, nilai osmolalitas berada pada kisaran 280-295 $\mathrm{mOsm} / \mathrm{kg} \mathrm{H}_{2} \mathrm{O}$ [2]. Penentuan nilai osmolalitas dilakukan dengan menggunakan alat osmometer. Penelitian mengenai pengaruh osmolalitas 36 formula sediaan infus terhadap osmolalitas cairan tubuh telah dilakukan oleh Fazekas et al [3].

Dalam upaya lebih meningkatkan kualitas sediaan radiofarmaka yang dihasilkan oleh PTRR, perlu dilakukan penentuan nilai osmolalitas sediaan tersebut sebelum dikirimkan ke rumah sakit. Alat yang digunakan untuk mengukur osmolalitas sediaan yang diproduksi oleh PTRR harus telah tervalidasi. Dalam pengukuran osmolalitas, diperlukan larutan standar yang sesuai dengan kisaran osmolalitas sediaan yang akan diukur. Secara umum, sediaan yang isotonis adalah $\mathrm{NaCl} 0,9 \%$, dengan osmolalitas sekitar 280 $\mathrm{mOsm} / \mathrm{kg}$ [4].

Validasi adalah suatu kegiatan untuk mengonfirmasikan bahwa suatu alat uji atau metode uji memenuhi persyaratan yang ditentukan untuk maksud tertentu, dengan cara menguji alat uji dan metode uji tersebut serta melengkapinya dengan bukti-bukti yang objektif. Pendekatan yang biasa dilakukan untuk validasi alat uji dan metode uji meliputi presisi, akurasi, kepekaan, batas deteksi, selektivitas, dan spesivitas [5]. Laboratorium pengujian yang mengadopsi peraturan SNI17025-2005 mensyaratkan data hasil uji dinyatakan absah apabila mempunyai presisi dan akurasi yang baik [6].

Akurasi (ketelitian/kecermatan) dalam analisis kimia adalah ukuran perbedaan atau kedekatan antara rerata hasil uji yang diperoleh dengan contoh yang homogen pada kondisi tertentu [6]. Presisi adalah ukuran yang menunjukkan derajat kesesuaian antara hasil uji individual, yang diukur melalui penyebaran hasil individual dari rerata jika prosedur diterapkan secara berulang pada sampel yang diambil dari campuran yang homogen. Presisi pengukuran diketahui dengan melakukan uji ripitabilitas, yang merupakan presisi metode yang dilakukan berulang kali dengan analisis yang sama, pada kondisi yang sama, dan dalam interval waktu yang pendek [7].

Secara singkat hubungan antara data presisi dan akurasi yang terbagi dalam beberapa kelompok berdasarkan sebarannya ditunjukkan pada Gambar 1.

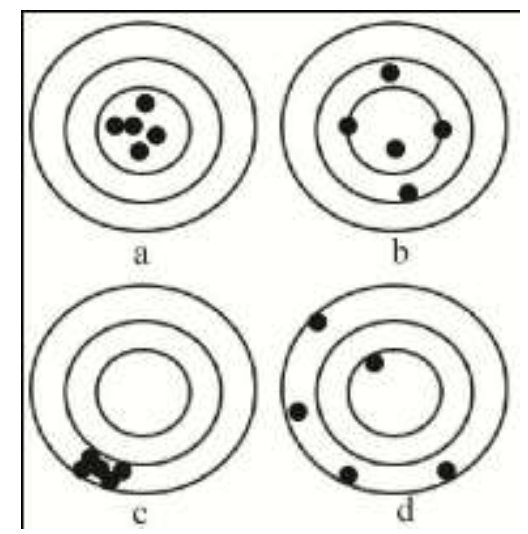

Gambar 1. a. Presisi dan akurasi tinggi; b. Presisi rendah, akurasi tinggi; c. Presisi tinggi, akurasi rendah; d. Presisi dan akurasi rendah.

Hubungan antara validasi presisi dan akurasi pengukuran dapat menentukan apakah alat tersebut masih berfungsi baik atau tidak, dengan melihat distribusi hasil pengukuran pada nilai standar deviasinya. Hasil pengukuran yang berada dalam range $\pm 1 \mathrm{SD}$ menunjukkan bahwa alat sangat bagus, hasil pengukuran dalam range $\pm 2 \mathrm{SD}$ menyatakan bahwa alat bagus, hasil pengukuran yang terdistribusi dalam \pm 3 SD menunjukkan bahwa alat berada dalam status "peringatan", dan jika hasil pengukuran dalam range lebih dari $\pm 3 \mathrm{SD}$ berarti alat sudah harus diperbaiki [8].

Tujuan penelitian ini adalah memvalidasi alat automatic osmometer sehingga pengukuran osmolalitas yang dihasilkan memiliki pemastian mutu yang valid. Dalam penelitian 
ini akan digunakan tiga parameter validasi, yaitu akurasi, presisi, dan linearitas.

\section{METODE PENELITIAN}

\section{Alat dan Bahan}

Alat-alat yang digunakan pada penelitian ini yaitu automatic osmometer, tabung Osmette, tabung sampel (Osmette $\mathrm{A}^{\mathrm{TM}}$ model 5002).

Bahan-bahan yang digunakan pada metode ini yaitu bath liquid, larutan standar 100, 290, $500 \mathrm{mOsm} / \mathrm{kg} \mathrm{H}_{2} \mathrm{O}$ (Precision System, Inc., Natick, Mass., USA.)

\section{Kalibrasi Alat}

Disiapkan tabung bersih dan kering, kemudian diisi bath liquid $0,5 \mathrm{ml}$. Selanjutnya dilakukan running alat. Kemudian disiapkan tabung sampel yang masing-masing diisi $0,5 \mathrm{ml}$ larutan standar $100 \mathrm{mOsm} / \mathrm{kg}$ dan larutan standar $500 \mathrm{mOsm} / \mathrm{kg}$. Setelah itu, tabung yang berisi sampel dimasukkan ke dalam refrigerator well.

Alat mulai beroperasi dan tunggu beberapa menit hingga lampu $R E A D$ berkedip dan nilai muncul pada display. Tahap terakhir, saklar operate diubah menjadi special dan dilakukan kalibrasi dengan memutar tombol CAL 1 untuk standar $500 \mathrm{mOsm} / \mathrm{kg}$ dan CAL 2 untuk standar $100 \mathrm{mOsm} / \mathrm{kg}$ [9].

\section{Validasi Pengukuran Akurasi}

Parameter akurasi dilakukan dengan mengukur larutan standar yang terdiri atas standar 100, 290, dan $500 \mathrm{mOsm} / \mathrm{kg}$. Batas pengukuran validasi menurut Purwanto et al. [6] minimal 6 kali pengukuran, menurut Harmita [10] minimal 8 kali pengukuran, dan menurut Mcpolin [11] minimal 9 kali pengukuran. Pada penelitian ini pengukuran dilakukan sebanyak 20 kali untuk memperkecil kesalahan pengukuran. Kemudian dicatat nilai osmolalitas yang tertera di display. Dihitung rerata hasil pengukuran tiap larutan standar, dihitung persen akurasi, dan dibuat tabel akurasi.

\section{Validasi Pengukuran Presisi}

Dilakukan pengukuran presisi dengan mengukur larutan standar yang terdiri atas standar 100, 290, dan $500 \mathrm{mOsm} / \mathrm{kg}$ sebanyak 20 kali pengukuran. Kemudian dicatat nilai osmolalitas yang tertera di display. Setelah itu, dihitung rerata hasil pengukuran tiap larutan standar dan dihitung standar deviasinya $\pm 1 \mathrm{SD}, \pm 2 \mathrm{SD}$, dan \pm 3 SD. Kemudian dibuat kurva presisi.

\section{Validasi Pengukuran Linearitas}

Dilakukan pengukuran linearitas larutan standar yang terdiri dari standar 100, 290, dan $500 \mathrm{mOsm} / \mathrm{kg}$ sebanyak 20 kali pengukuran. Dicatat nilai osmolalitas yang tertera di display. Kemudian dihitung rerata hasil pengukuran tiap larutan standar. Dibuat kurva linearitas dan persamaan regresinya.

\section{HASIL DAN PEMBAHASAN}

Pengukuran osmolalitas dengan alat automatic osmometer dilakukan sebanyak 20 kali dengan menggunakan tiga standar, yaitu 100, 290, dan $500 \mathrm{mOsm} / \mathrm{kg}$. Untuk parameter akurasi dan presisi hasilnya sudah memenuhi standar validasi. Adapun untuk parameter linearitas yang seharusnya memerlukan 5 standar belum bisa terpenuhi karena standar yang ada pada alat hanya ada 3 standar. Data hasil pengukuran osmolalitas larutan standar ditunjukkan pada Tabel 1.

Tabel 1. Hasil Pengukuran Osmolalitas Larutan Standar 100, 290, dan $500 \mathrm{mOsm} / \mathrm{kg}$

\begin{tabular}{cccc}
\hline Parameter & $\begin{array}{c}\text { Standar 100 } \\
\text { mOsm/Kg }\end{array}$ & $\begin{array}{c}\text { Standar 290 } \\
\text { mOsm/kg }\end{array}$ & $\begin{array}{c}\text { Standar 500 } \\
\text { mOsm/kg }\end{array}$ \\
\hline Rerata & 100.0500 & 290.1500 & 502.1000 \\
Range & $97-103$ & $288-294$ & $488-506$ \\
SD & 1.7006 & 1.3870 & 2.0494 \\
RSD & $1.70 \%$ & $0.48 \%$ & $0.41 \%$ \\
\hline
\end{tabular}

Pada Tabel 1 didapatkan hasil pengukuran rerata pada $100 \mathrm{mOsm} / \mathrm{kg}$ sebesar 100,05 \pm $1,70 \%$, sedangkan rerata pada $290 \mathrm{mOsm} / \mathrm{kg}$ sebesar $290,15 \pm 0,48 \%$, dan rerata pada 500 $\mathrm{mOsm} / \mathrm{kg}$ sebesar $502,10 \pm 0,41 \%$. Hasil ini didapatkan dari 20 kali pengukuran sehingga nilai standar deviasi 100,290 , dan 500 $\mathrm{mOsm} / \mathrm{kg}$ juga bervariasi. Dilihat dari RSD yang dihasilkan, menurut Harmita [10], semuanya memenuhi syarat karena dari ketiga nilai RSD standar tidak ada yang lebih dari $2 \%$.

Pada penelitian ini telah dilakukan validasi akurasi pengukuran osmolalitas larutan standar dan hasil selengkapnya ditunjukkan pada Tabel 2. 
Tabel 2. Persentase Akurasi Hasil Pengukuran Osmolalitas Larutan Standar 100, 290, dan 500 $\mathrm{mOsm} / \mathrm{kg}$

\begin{tabular}{cccc}
\hline No. & $\begin{array}{c}\text { Larutan } \\
\text { Standar } \\
\text { (mOsm/kg) }\end{array}$ & $\begin{array}{c}\text { Rerata Hasil } \\
\text { Pengukuran } \\
\text { (mOsm/kg) }\end{array}$ & $\begin{array}{c}\text { Akurasi } \\
\text { (\%) }\end{array}$ \\
\hline 1 & 100 & 100.05 & $100,05 \%$ \\
2 & 290 & 290.15 & $100.05 \%$ \\
3 & 500 & 502.10 & $100,42 \%$ \\
\hline
\end{tabular}

Tabel 2 menunjukkan nilai akurasi pengukuran alat terhadap larutan standar 100 $\mathrm{mOsm} / \mathrm{kg}$, dengan nilai rerata 100,05 $\mathrm{mOsm} / \mathrm{kg}$, yakni $100,05 \%$. Pada pengukuran larutan standar $290 \mathrm{mOsm} / \mathrm{kg}$ didapatkan hasil rerata $290,15 \mathrm{mOsm} / \mathrm{kg}$, dengan tingkat akurasi $100,05 \%$, sementara pada larutan standar $500 \mathrm{mOsm} / \mathrm{kg}$ terjadi kenaikan nilai rerata sebesar 502,10 $\mathrm{mOsm} / \mathrm{kg}$, dengan akurasi 100,42\%. Hasil tersebut menunjukkan bahwa alat osmometer dapat mengukur osmolalitas larutan standar $100 \mathrm{mOsm} / \mathrm{kg}$ dengan nilai akurasi $100,05 \%$ atau penyimpangan $0,05 \%$ dari nilai sebenarnya. Demikian juga pada pengukuran larutan standar $290 \mathrm{mOsm} / \mathrm{kg}$ diperoleh nilai akurasi $100,05 \%$ atau penyimpangan $0,05 \%$, sedangkan pada pengukuran standar 500 $\mathrm{mOsm} / \mathrm{kg}$ diperoleh nilai akurasi $100,42 \%$ atau penyimpangan $0,42 \%$ dari nilai sebenarnya. Hal ini menunjukkan bahwa alat osmometer tersebut sangat akurat untuk mengukur osmolalitas antara 100 sampai $500 \mathrm{mOsm} / \mathrm{kg}$ sesuai dengan kriteria persentase akurasi menurut Sugihartini et al. [12], yang menyatakan bahwa hasil pengukuran dinyatakan akurat jika persentase akurasi 98$102 \%$.

Selanjutnya, dilakukan validasi presisi pengukuran pada rentang osmolalitas 100 hingga $500 \mathrm{mOsm} / \mathrm{kg}$. Hasil selengkapnya ditunjukkan pada Gambar 2, 3, dan 4.

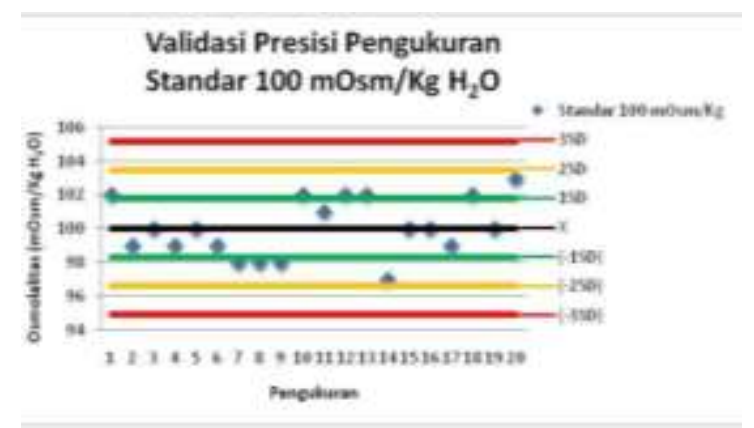

Gambar 2. Grafik Validasi Presisi Pengukuran Standar $100 \mathrm{mOsm} / \mathrm{kg} \mathrm{H}_{2} \mathrm{O}$
Pada Gambar 2 ditunjukkan hasil validasi presisi pengukuran standar $100 \mathrm{mOsm} / \mathrm{kg}$. Hasil pengukuran terdistribusi dalam range \pm 1 SD sebesar 50\%, dan \pm 2 SD sebesar 50\%. Hal ini menunjukkan bahwa pengukuran osmolalitas alat automatic osmometer untuk larutan standar $100 \mathrm{mOsm} / \mathrm{kg}$ masih berfungsi dengan baik karena tidak ada hasil pengukuran yang terdistribusi pada $\pm 3 \mathrm{SD}$.

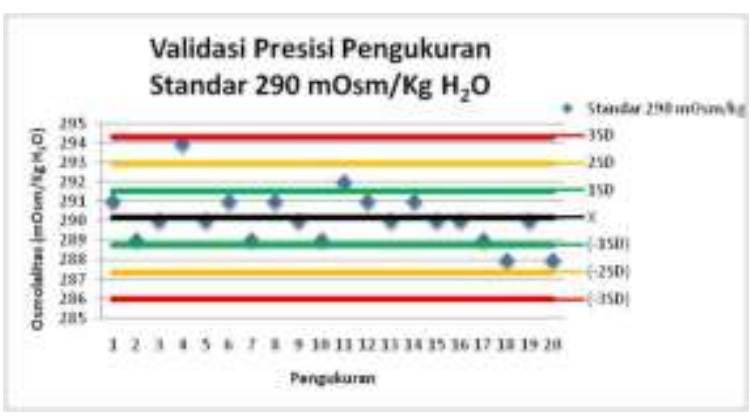

Gambar 3. Grafik Validasi Presisi Pengukuran Standar $290 \mathrm{mOsm} / \mathrm{kg} \mathrm{H}_{2} \mathrm{O}$

Pada Gambar 3 ditunjukkan hasil validasi presisi pengukuran $290 \mathrm{mOsm} / \mathrm{kg}$. Hasil pengukuran mayoritas terdistribusi pada \pm 1 SD sebesar $80 \%$, hasil pengukuran yang terdistribusi pada \pm 2 SD sebesar $15 \%$, dan hanya ada satu data $(5 \%)$ yang berada di area \pm 3 SD. Hal ini terjadi karena warming up alat kurang lama. Idealnya, pengukuran dilakukan setelah alat benar-benar stabil. Namun jika dilihat dari nilai RSD, hasil pengukuran osmolalitas $290 \mathrm{mOsm} / \mathrm{kg}$ sebesar $0,48 \%$ dan berdasarkan Harmita [10], yang menyatakan bahwa hasil pengukuran dikatakan presisi jika nilai $\mathrm{RSD} \leq 2 \%$, dapat dinyatakan bahwa alat automatic osmometer tersebut masih baik (presisi) jika digunakan dalam pengukuran osmolalitas larutan $290 \mathrm{mOsm} / \mathrm{kg}$.

Beberapa faktor yang dapat mempengaruhi hasil pengukuran adalah: volume sampel yang diukur (minimal 0,5 ml), suhu sampel yang diukur (sesuai suhu kamar), sampel yang telah diukur tidak dapat lagi digunakan (expired), tabung dan pipet yang digunakan harus dalam keadaan bersih dan kering, pengaturan stirrer pada alat osmometer harus disesuaikan, warming up alat minimal 15 menit sebelum digunakan. 


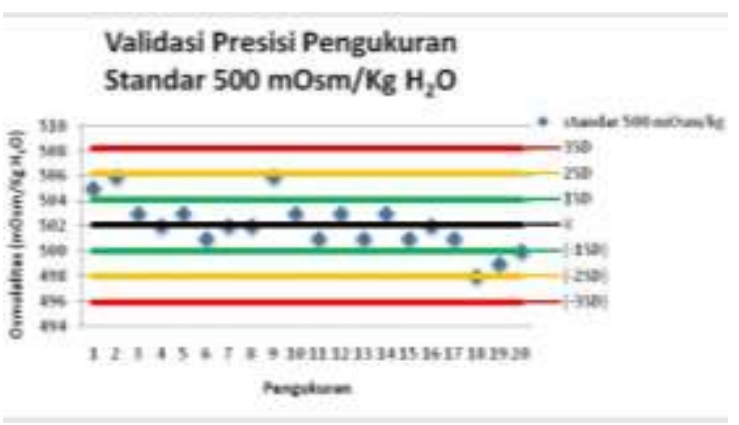

Gambar 4. Grafik Validasi Presisi Pengukuran Standar $500 \mathrm{mOsm} / \mathrm{kg} \mathrm{H}_{2} \mathrm{O}$

Pada Gambar 4 ditunjukkan hasil validasi presisi pengukuran standar $500 \mathrm{mOsm} / \mathrm{kg}$ terdistribusi pada \pm 1 SD sebesar $75 \%$, sedangkan hasil distribusi pada \pm 2 SD sebesar $25 \%$. Hal ini menunjukkan bahwa pengukuran alat automatic osmometer untuk larutan standar $500 \mathrm{mOsm} / \mathrm{kg}$ masih baik karena data hasil pengukuran hanya terdistribusi mayoritas pada \pm 1 SD dan sebagian kecil pada \pm 2 SD.

Selanjutnya, dilakukan validasi linearitas pengukuran pada rentang osmolalitas 100 hingga $500 \mathrm{mOsm} / \mathrm{kg}$. Hasil selengkapnya ditunjukkan pada Gambar 5.

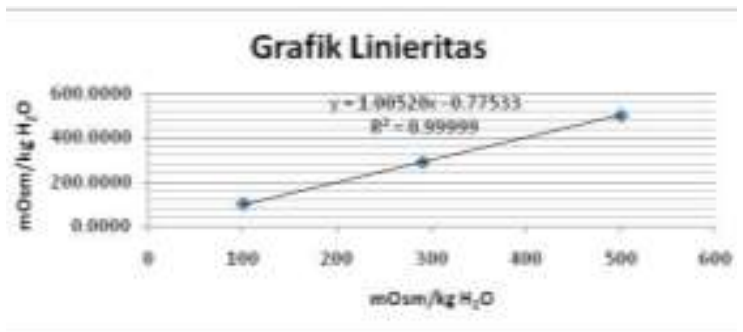

Gambar 5. Grafik Linearitas Pengukuran Standar 100-500 mOsm/ $/ \mathrm{kg} \mathrm{H}_{2} \mathrm{O}$

Linearitas dinyatakan dalam istilah variansi sekitar arah garis regresi, yang dihitung berdasarkan persamaan matematis data yang diperoleh dari hasil analisis unsur dalam larutan standar dengan berbagai konsentrasi (deret standar), seperti yang dinyatakan oleh Sugihartini et al. [12] bahwa linearitas dapat ditentukan dengan pengukuran pada beberapa konsentrasi analit. Nilai slope (b), intersep (a), dan koefisien korelasi $\left(\mathrm{r}^{2}\right)$ menggambarkan informasi linearitas. Pada Gambar 5 ditunjukkan nilai linearitas pada rerata hasil pengukuran, yaitu $\mathrm{a}=1,00520, \mathrm{~b}=$ 0,77533 , dan $r^{2}=0,99999$. Nilai $r^{2}$ yang mendekati 1 menunjukkan bahwa alat osmometer masih valid (linier) untuk pengukuran osmolalitas pada rentang 100 hingga $500 \mathrm{mOsm} / \mathrm{kg}$ [7].

\section{KESIMPULAN}

Dari hasil validasi pengukuran nilai osmolalitas larutan standar berdasarkan parameter akurasi, presisi, dan linearitas, maka dinyatakan bahwa alat automatic osmometer valid untuk mengukur osmolalitas sediaan radiofarmaka di PTRR.

\section{DAFTAR PUSTAKA}

1. Zimmer, A.M. and S.M. Spies, 1991. "Quality Control Procedures for Newer Radiopharmaceutical", in: $\mathrm{Nucl}$. Med. Technol., Vol. 19, No. 4, pp. 210-214.

2. Earnest, A. and G.M. Susla, 2012. "Syndrome of Inappropriate Antidiuretic Hormone and Cerebral Salt Wasting in Critically III Patients", in: $A A C N A d v$. Crit. Care, Vol. 23, No. 3, pp. 233-239.

3. Fazekas, A.S., G.C. Funk, D.S. Klobassa, H. Ruther, I. Ziegler, R. Zander, and H.J. Semmelrock, 2013. "Evaluation of 36 Formulas for Calculating Plasma Osmolality", in: Intensive Care Med., Vol. 39, No. 2, pp. 302-308.

4. Bazmi, B.A., A.K. Singh, S. Kar, and H. Mubtasum, 2013. "Storage Media for Avulsed Tooth", in: Indian J. Multidiscip. Dent., Vol. 3, No. 3, pp. 741-749.

5. Supriyanto, C. and S. TS, 2006. "Validasi Metode F-AAS untuk Memperoleh Jaminan Mutu pada Analisis Unsur Cd, $\mathrm{Cu}, \mathrm{Cr}, \mathrm{Pb}$, dan $\mathrm{Ni}$ dalam Contoh Uji Limbah Cair", dalam: Pros. PPI PDIPTN, pp. 121-125.

6. Purwanto, A., C. Supriyanto, and P. Samin, 2007. "Validasi Pengujian $\mathrm{Cr}, \mathrm{Cu}$, dan $\mathrm{Pb}$ dengan Metode Spektrometri Serapan Atom", dalam: Pros. PPI PDIPTN, pp. 151-158.

7. Noerpitasari, E. and A. Nugroho, 2012. "Validasi Metode Analisis Unsur Tanah Jarang $(\mathrm{Ce}, \mathrm{Eu}, \mathrm{Tb})$ dengan Alay ICP-AES Plasma 40," dalam: Semin. Nas. VIII SDM Teknol. Nukl., pp. 347-352.

8. Achmad, F., S. Rahayu, and Y. Sumarriani, 2010. "Penerapan Grafik-X dan Grafik-R sebagai Grafik Kendali dalam Pengujian Kualitas Air", dalam: $J$. Stand., Vol. 12, No. 1, pp. 14-19.

9. Anonim, 2011. "Operator's Manual of Osmette $A^{\mathrm{TM}}$ Model 5002 Automatic Osmometer", in: Cat. \#2093, pp. 1-42.

10. Harmita, 2004. "Petunjuk Pelaksanaan Validasi Metode dan Cara 
Perhitungannya", dalam: Majalah Ilmu Kefarmasian, Vol. I, No. 3, pp. 117-135.

11. Mcpolin, O. 2009. Validation Of Analytical For Pharmaceutical Analysis. Northern Ireland: Mourne Training Services.

12. Sugihartini, N., A. Fudholi, S. Pramono, and Sismindari, 2012. "Validation Method of Quantitative Analysis of Epigallocathecin Gallat by Thin Layer Chromatography", dalam: Ilm. Kefarmasian, Vol. 2, No. 1, pp. 81-87. 